\title{
WHY GANYMEDE FAINTS AND THE DUKE OF YORK WEEPS: PASSION PLAYS IN SHAKESPEARE
}

\author{
SUJATA IYENGAR
}

This essay revisits contemporary critical debates surrounding the presence of cross-dressed boys as women on the early modern stage - in particular the question of whether or to what extent boy-actors could or should be said to represent 'women' or 'femininity' - through the Shakespearian emblem of the bloody rag or handkercher. In all but one instance, these soiled napkins appear alongside what the plays call 'passion' of various kinds. I will examine bloody rags on Shakespeare's stage in the light of early modern anti-theatrical polemics, medical disputes about sex-difference, and the conflicted cultural status of printed paper in order to argue that these besmirched tokens bring together early modern 'passions' in multiple senses: strong or overpowering, embodied feeling; the fluid dynamics of early modern bodies; the Passion of Christ; erotic suffering; and, crucially, the performance on stage of all of the above. ${ }^{\text {I }}$

With the aid of Fran Teague's useful tables in Shakespeare's Speaking Properties, I count the following blood-stained or red-marked rags on Shakespeare's stage: in The True Tragedy of Richard Duke of York and the Good King Henry the Sixth (3 Henry $V I$ ), the monstrous, magnificent Queen Margaret forces tears from the captured Duke of York by asking him to wipe his face with a handkerchief imprinted with the dying blood of his youngest son. ${ }^{2}$ In A Midsummer Night's Dream, or rather, in the parodic play of 'Pyramus and Thisbe' performed by the rude mechanicals in Act 5 , Pyramus broaches his boiling bloody breast after catching up Thisbe's bloodstained mantle. In As You Like It, Rosalind, disguised as the boy Ganymede, faints when faced with a cloth sodden with Orlando's blood. We could include the napkin 'spotted' with strawberries in The Tragedy of Othello, the Moor of Venice that the eponymous hero takes as a token of his wife's infidelity, although the napkin is not presented theatrically as specifically stained with blood. In Cymbeline King of Britain, Posthumus Leonatus keeps safe about his body a cloth coloured with, as he believes, the blood of the wife whose murder he has sanctioned.

These bloodied, reddened, marked, or spotted handkerchiefs, napkins and cloths have received some critical attention, mostly surrounding their semiotic significance as religious relics and proxies for female uncontrollability. Stained cloths and rags on Shakespeare's stage, and particularly in Othello and Cymbeline, critics suggest, control women both by standing in for their chastity or sexual temperance and by drawing attention to what Gail Kern Paster has called women's humoral 'leakiness'. ${ }^{3}$ Will Fisher identifies handkerchiefs (new to England in the sixteenth century) as portable, transferable bearers of gender, important in 'materializing early modern notions of femininity' through

\footnotetext{
I I would like to thank Peter Holland, Katharine Craik and the members of the seminar 'Passionate Shakespeare' at the International Shakespeare Conference in 2012 for their responses to this essay.

2 Frances N. Teague, Shakespeare's Speaking Properties (Lewisburg, Toronto, and London, I99I), pp. I9I-6.

3 Gail Kern Paster, The Body Embarrassed: Drama and the Disciplines of Shame in Early Modern England (Ithaca, I993), esp. ch. 3, 'Laudable Blood', pp. 64-I I2.
} 


\section{SUJATA IYENGAR}

their ability simultaneously to absorb unmentionable or unwelcome female or feminizing fluids and to display wealth and social status. ${ }^{4}$ Teague reads the spotted handkerchief on Othello in multiple ways, as a 'symbol of self or of jealousy, emblem of treachery, and literal magic token'.5 Marion Lomax comments upon the 'conflicting, yet here, strangely compatible notions of human sexual passion and Christ's Passion' through the bloody cloth that Posthumus takes as evidence of Innogen's death in Cymbeline and through the five 'crimson' spots under Innogen's left breast: stigmata, Lomax suggests, that connect the saintly wife to icons of female virtue. For Lomax, the bloody rag as relic beatifies the wounded wife, and Posthumus's remorse at the sight of this token redeems him. ${ }^{6}$ Valerie Wayne argues more explicitly for Posthumus's recuperation through the stained cloth, describing the stage-tradition that Posthumus wears the cloth on his body and associating the cloth with both 'the bloodstained sheets of a marriage bed - like the handkerchief spotted with strawberries in Othello... as well as with menstruation'. 7 Richard Wilson analyses bloody or spotted handkerchiefs on Shakespeare's stage, and particularly in Othello, as emblems of Catholic relics, rags steeped in the blood of martyrs, and as 'the despised supplement of menstruation', markers of an uncontrollable or 'leaky' femininity and of, Wilson continues, a polylingual or 'leaky' paronomasia (first identified by Patricia Parker) that connects the Moor of Venice, moresca embroidery, the Catholic martyr Sir Thomas More and the latter's joking emblem, the mulberry tree or morus that changes colour from white to red to black as it ripens. ${ }^{8}$ Ariane Balizet (in a series of essays, and in her forthcoming book) outlines the associations of menstruation with blood that connotes contamination, contagion and inferiority, that is, that which is culturally, medically, and religiously subordinated and feminine, although she considers stained napkins as hymeneal signifiers of domesticity in a Reformed church: 'Just as the strawberry-spotted handkerchief in Shakespeare's Othello, for example, could signify the bloodied wedding sheets that seal the marriage pact, the bloody handkerchief in The
Duchess of Malfi stands in for the bloodied birthingbed linens. In both cases, the bloody handkerchief becomes a miniaturized version of a private act that cannot be shown onstage (sex and birth) and signifies the initiation of a domestic realm unique to its inhabitants.'

Wilson helpfully adduces Garry Wills' observation that 'Handkerchiefs were associated with the public execution of Jesuits [in England], since the emptying of all a man's blood in the savage disemboweling, castrating, and quartering of the hanged bodies of traitors prompted pious Catholics to dip handkerchiefs and other bits of cloth in the martyrs' saving blood.' ${ }^{\text {Io }}$ Wilson, however, unnecessarily opposes the two categories of holy relic and menstrual rag when he contrasts the work of 'feminists who see only hymeneal connotations' to accounts that emphasize Shakespeare's engagement with debates about Catholicism. ${ }^{\text {II }}$ In fact as Wilson's own fine work implies as and I will go on to discuss - a long-standing tradition within Protestant writing pejoratively compares Catholic

4 Will Fisher, 'Handkerchiefs and Early Modern Ideologies of Gender', Shakespeare Studies, 28 (2000), I99-207, p. 20 I.

5 Teague, Shakespeare's Speaking Properties, p. 27.

6 Marion Lomax, Stage Images and Traditions: Shakespeare to Ford (Cambridge, I987), pp. I07-9, esp. p. I07.

7 Valerie Wayne, 'The Woman's Parts of Cymbeline', in Staged Properties in Shakespeare's Drama, ed. Jonathan Gil Harris and Natasha Korda (Cambridge, 2002), pp. 288-3 I 5, p. 298.

8 Richard Wilson, "'Dyed in Mummy": Othello and the Mulberries', in Performances of the Sacred in Late Medieval and Early Modern England, ed. Susanne Rupp and Tobias Döring (Amsterdam, 2005), pp. I35-I54, p. I46; Patricia Parker, Shakespeare from the Margins (Chicago, I996), p. 275 n.II; Patricia Parker, 'What's in a Name: and More', Sederi XI (Huelva, 2002), IOI-49.

9 Ariane Balizet, "'Drowned in Blood": Honor, Bloodline, and Domestic Ideology in The Duchess of Malfi and El médico de su honra', Comparative Literature Studies, 49. I (2012), 23-49, p. 44. See also Balizet's forthcoming book, 'Blood and Home in Early Modern Drama' (Routledge), which independently comments upon blood-stained napkins in The Tragedy of Othello, the Moor of Venice, As You Like It and Cymbeline King of Britain as indicators of the 'liminality' of binary gender.

Io Garry Wills, Witches and Jesuits: Shakespeare's Macbeth (Oxford and New York, I996), p. 99.

I Wilson, 'Dyed in Mummy', p. I 50. 


\section{PASSION PLAYS IN SHAKESPEARE}

practices of image-worship and even the performance of good works not just to blood-soaked rags or relics of martyrdom in general but to women's menstrual cloths in particular: the Passion of Christ to what Stephen Batman, translating the medieval medical authority Bartolomeus Anglicus and synthesizing other early Christian medical texts, calls 'the passion menstruall'. ${ }^{\mathrm{I} 2}$ Moreover, at moments of gender and sexual crisis, the bodies of Shakespearian characters express the 'wrong' gender for their circumstances when faced with bloody rags, although they do so with different degrees of 'passion'.

\section{'NO MAN HATH THE PASSION MENSTRU A L L}

Thomas Laqueur's influential Making Sex argued that a so-called 'one-sex' model predominated in England and Western Europe during the sixteenth and early seventeenth centuries in which orthodox early modern Galenic medicine (which, he suggests, was itself a modification of the Aristotelian theory that women were 'imperfect' men who had not fully developed in utero because they lacked sufficient heat) considered both men and women part of a single-sex continuum, with women as merely 'inverted' men who could, under the appropriate stimuli, develop organs thought to belong to the opposite sex. Moreover, suggests Laqueur, humoral theory meant that both genders were able to perform functions that we now consider specific to a single sex. For example, women could ejaculate seed during orgasm, stimulated by heat-generating friction or other methods of arousal (some authorities, indeed, maintained that sexual climax was necessary for conception to occur because women's seed would not be available for fertilization without it), and men, given sufficient chill and moisture, could lactate. ${ }^{\mathrm{I} 3}$ Gail Kern Paster, Katharine Park, Winfried Schleiner and Helen King have, however, challenged Laqueur's larger argument by identifying early modern medical beliefs that considered certain aspects of embodiment to be inescapably female: women's bodily integrity, bodily fluids, and the social policing of these bodies and fluids (Paster); newly 'discovered' female organs such as the clitoris (Park); Galenic proto-feminism that saw women not as 'imperfect men' but as 'perfect in their own sex' (Schleiner); and an Aristotelian discipline of 'gynecology', a specific science pertaining to a definitively female sex with its own distinct maladies (King). ${ }^{\mathrm{I}}$ In addition, Paster and Schleiner argue that menstruation contributed to an ongoing belief in sexual dimorphism, both medical and popular. Paster observes the stigma associated with women's (implicitly menstrual, or child-bearing) blood, in contrast to men's 'laudable' bloodshed through the wounds of war. Schleiner argues for an early modern, protofeminist Galenism: women menstruated not as a sign of their innate pathology - not because they were imperfect men who bled away the precious sanguine humour since they had a plethora of too much blood or a cachochymia, an overdose of moist phlegm, as Laqueur maintains - but because healthy, fertile femininity required women to make more blood in preparation for a potential fetus, and to purge this blood when it became too old or corrupted. Bethan Hindson, a social historian, surveys early modern diaries, histories, and printed texts to investigate popular attitudes towards menstruation, and although she disagrees with Paster about the stigma of women's blood, finding female menstruation less 'embarrassing'

I2 Bartolomeus Anglicus, De Proprietatibus Rerum, newly corrected, enlarged and amended: with . . additions, trans. and ed. Stephen Batman (London, I582), D2v, col. 2.

13 Thomas Laqueur, Making Sex: Body and Gender from the Greeks to Freud (Cambridge, MA, I990), esp. ch. 2, 'Destiny is Anatomy', pp. 26-62.

I4 Gail Kern Paster, The Body Embarrassed: Drama and the Disciplines of Shame in Early Modern England (Ithaca, I993), passim; Katharine Park, 'The Rediscovery of the Clitoris', in The Body in Parts, ed. David Hillman and Carla Mazzio (London and New York, I997), pp. I75-9; Winfried Schleiner, 'Early Modern Controversies About the One-Sex Model', Renaissance Quarterly, 53:I (2000), I80-9I; Helen King, Midwifery, Obstetrics, and the Rise of Gynaecology: The Use of a SixteenthCentury Compendium (Farnham, 2007), esp. 'Introduction: Towards Gynaecology' and ch. I, 'Prefacing Women: Owners and Users', pp. I-64. 


\section{SUJATA IYENGAR}

than routine in early modern life, she concurs that menstruation marks a distinctly female sex. ${ }^{\text {I5 }}$ Although Laqueur parallels male episodic bleeding from the anus to female monthly bleeding from the vagina, Hindson and others find that accounts of so-called male menstruation refer to sporadic anal bleeding from haemorrhoids or bloody flux (dysentery), rather than to the periodic evacuation of fetal sustenance from the body. Physicians and lay-people alike recognized that only women menstruated, and sustained pregnancies.

Women's relationship to blood necessarily affected their experience of passion. Passions and perturbations disrupted the balance of humours in all bodies, male and female. Under the strain of great emotion, blood rushed to the heart from the liver (where it was manufactured) in order to sustain and support it. Joy, delight and pleasant emotions expanded or opened the heart, while fear, misery and hatred contracted or tightened it. Although pleasurable feelings might temporarily affect one's reason, they were, on the whole, beneficial to the health because they helped the formation of pure blood and of natural, vital and animal spirit in the liver, heart and brain respectively. Spirit both nourished these organs and was further refined by them; more importantly, spirituous blood provided the link between body and soul. A surfeit of joy, however, would enlarge the heart to dangerous levels and create a plethora, or overload, of blood within it; the resultant heat could turn the blood into choler (the thin, sharp, hot, dry humour, which weakened the heart and could cause deaths after fits of laughter) or into choler adust (burned choler) or melancholy (the thick, sour, cold, dry humour, which caused the depression that some experienced after excessively radiant pleasure). But far more perilous were the passions of fear and sorrow, in which heavy, dull melancholy overwhelmed the sanguine humour of blood and slowed the movement of spirit through the body. When the heart retained blood in this manner, the blood congealed into melancholy proper, which cooled and dried the whole body. An excess of any emotion, however - any passion or perturbation - would o'ercharge the heart. Shakespeare's
Angelo describes the process as he almost swoons with desire for Isabel:

Why does my blood thus muster to my heart, Making both it unable for itself, And dispossessing all my other parts Of necessary fitness?

So play the foolish throngs with one that swoons Come all to help him, and so stop the air By which he should revive...

$$
\text { (Measure for Measure, 2.4.20-6) }
$$

Angelo's heart is overwhelmed by too much blood, too quickly: it can neither mix the blood with air to produce the vital spirit necessary for the heart's nourishment and also as the precursor to the animal or rational spirit in the brain ('dispossessing all my other parts / Of necessary fitness'), nor can it continue beating regularly and consume the blood that would normally sustain it ('making ... it unable for itself'). The blood musters to his heart as concerned bystanders crowd around a fainting man who then, like his blood itself, cannot obtain the air he needs in order to recover.

Helkiah Crooke observes in his discussion of 'passions of the mind' that women are more liable than are men to swooning and fainting. He argues that women's hearts resemble their wombs in that they, too, are vulnerable to environmental stimuli and emotional upset (as in the specifically female and uterine disorder of hysterica passio). ${ }^{\mathrm{I} 6}$ I have argued elsewhere that 'it is mostly Shakespeare's women who swoon' (although men feel apt to swoon when overwhelmed with erotic desire) but that 'both Shakespeare's men and women might faint'. ${ }^{17}$ Shakespearian swoons stem from passion

\footnotetext{
Is Bethan Hindson, 'Attitudes towards Menstruation and Menstrual Blood in Elizabethan England', Journal of Social History, 43: I (2009), 89-I I4.

I6 Helkiah Crooke, Microcosmographia (London, I6 I 5), Book 7, Vv6r; Book 4, Zr. On hysterica passio, see Kaara Peterson, Popular Medicine, Hysterical Disease, and Social Controversy in Shakespeare's England (Farnham and Burlington, VT, 2010), ch. I, 'Early Modern Medicine and the Case History of King Lear', pp. 37-69, esp. pp. 62-9.

I7 Sujata Iyengar, Shakespeare's Medical Language (London, 2OII), p. I33.
} 


\section{PASSION PLAYS IN SHAKESPEARE}

and perturbation - the result of the body's consuming vital and rational spirit more quickly than the heart and brain can produce them, whether because the heart contracts under negative emotions, or because blood or spirit rushes too quickly to the heart, preventing rational spirit from reaching the brain - but Shakespearian faints might come from passionate stimuli (especially when cowardice, grief, or fear have used up vital spirit in the heart) as well as from external physical events such as blood loss in battle, weakness from travel, or starvation (and women might faint in pregnancy, given the growing hunger of the uterus for vital blood). Stephen Batman connects men's greater fortitude and strength to their larger hearts and their greater blood- and spirit-volume:

Also Constantine sayth, that in males the heartes be large and great, therefore they be able to receiue much plentie of spirites and of bloud: And therefore through the great abundaunce of spirits and hot bloud, a man is more hardy then a woman, for in her the cause is contrarie: And through strength of heate and vertue of drie complection, no man hath the passion menstruall as women haue. All superfluities that bee bread in mens bodyes, are eyther consumed by greate heate, or els turned into haire, or are voided by businesse and trauaile. ${ }^{18}$

In keeping with then-standard belief, Batman concludes that men can tolerate extreme emotions and hardship more effectively than can women because of a combination of their humoral composition (their greater heat, which allows an excess of blood to be burnt off without ill effects as sweat or vapour, or turned into what were called the 'excrements' such as hair, or nails) and their social status: hard-working men required, and diffused, more blood and heat as they conducted physical labour. Philip Barrough (I583) adds that '[W] omen of a hote temperature, that be wilde, and who vse strong exercises' (for example, 'barraine women and dauncers') were known to have similar needs, to such an extent that such women often failed to menstruate at all, because they had burned off all their excess blood through their vigorous activity. ${ }^{19}$ Oddly enough, women's greater supposed ability to weep tears of joy and sorrow - another 'excrement' - at times of great emotion apparently did not prevent them from swooning. So we might think of gendered passions in bloody terms: if one faints or swoons, it is because one lacks blood in the appropriate organs, as blood abandons the brain in order to try to protect the heart. But if a woman menstruates, she does so from plethora or too much blood - either pathological or (in proto-feminist Galenism) necessary for perfection or completion in her own sex.

\section{'BAWDY PLAYERS' AS 'MENSTRUOUS RAGGES'}

Given that menstruation is one of the few bodily functions specifically gendered female in early modern England, it is worth pausing to explore the range of figurative allusions to this process. As Sara Read has observed, references to menstrual cloths and rags in early modern religious treatises, sermons and so on repeat (through citation, commentary, and creative transformation) two verses from the Biblical book of Isaiah. ${ }^{20}$ In the Geneva Bible, Isaiah 30:22 urges the Israelites to 'pollute the couering of the images of siluer, and the riche ornament of thine images of golde, and cast them away as a menstruous cloth, and [...] say vnto it, Get thee hence'; and Isaiah 64:6 claims, 'we haue all bene as an vncleane thing, and all our righteousness is as filthie cloutes, and we all doe fade like a leafe, and our iniquities like the winde haue taken vs away'. Note $h$ explains, 'our righteousnes, and best vertues are before thee as vile clouts, or, (as some reade) like the menstruous clothes of a woman'. ${ }^{21}$

A quick look through Chadwyck-Healey's Bible in English database suggests that earlier English

I8 Stephen Batman, Batman Upon Bartholome (London, I 582), D2v, column 2.

I9 Philip Barrough, The Methode of Phisicke (London, I583), Book III, Chapter 53, Nr.

20 Sara Read, “Thy Righteousness is but a menstrual clout": Sanitary Practices and Prejudice in Early Modern England', Early Modern Women, 3 (2008), I-26.

2I The Bible (Geneva, I 560), 'To waite for the lord', p. $293 \mathrm{col}$. I, Ccciiir; 'Mans righteousness', p. 303v col. 2, Fff2v. 


\section{SUJATA IYENGAR}

Protestant English translations of Isaiah specifically identify the contaminant in Isaiah 64:6 as menstrual blood: our righteousness is as 'the cloth of the womman roten blod flowende' (Wycliff, Early), 'the cloth of a womman in vncleene blood' (Wycliff, Late), 'the clothes stayned with the floures of a woman' (Coverdale), a 'cloth fyled wyth the floures of a woman' (Great), or 'the clothes defyled with the floures of a woman' (Thomas Mathew), while Isaiah 64:6 in the three major Protestant translations of Shakespeare's lifetime appears as 'filthie cloutes' (Geneva), and 'filthy ragges' (Bishops', KJV). ${ }^{22}$ The late sixteenth- and early seventeenth-century Protestant consensus for 'filthy' over 'blood' or 'flowers' might seem to support Paster's assertion that menstruation in the late sixteenth-century becomes overwhelmingly identified with female bodies (thus, perhaps, the translators attempt to make universal an image that had become too specific to a limited range of persons) and that leaking female fluids became increasingly invisible or shameful, thus the term 'filthiness' rather than 'menstruous rag'. Read observes that seventeenth-century commentators, especially Protestants, prefer the less specific word 'filthy', to describe menstrual rags and suggests that the shift to filth, as it were, reflects an increasing disgust for the open display of women's bodies and discharges through the seventeenth century, that women themselves use the figure of filthiness less frequently than men do, and that the association with filth contributes to women's own relative silence about their own bodily wastes and their disposal.

But there is precedent for using 'filthy' to mean 'soiled with menstrual blood' as early as Coverdale's I 535 Bible, for the earlier reference, in Isaiah 30:22: 'Morouer yf ye destroye the syluer workes of youre Idols, and cast awaye the golden coapes that ye deckt them withall (as fylthynes) and saie, get you hence'. ${ }^{23}$ In addition, Isaiah 30:22 remains 'menstruous' in Geneva and KJV, even though Bishops' is (as is its wont) a little more elliptical, replacing the explicit 'menstruous' with the more general 'filthyness': 'euen as filthynesse shalt thou put them away: And thou shalt say vnto it, Get thee hence'. In contrast, the Catholic Rheims-Douai in 30:20 conflates the filthy cloth and the polluted woman whose bodily discharges have contaminated it: "And thou shalt contaminate the plates of the sculptils of thy siluer, and the garment of the molten of thy gold, and shalt scatter them as the vncleannes of a menstruous woman' and in Isaiah $64: 6$ retains the specifically female, and fertile, 'cloth of a menstrued woman'. ${ }^{24}$

Does 'filthy' in Geneva, Bishops', and KJV serve as intensifier, or as euphemism? Or does the very use of euphemism imply obscenity and disgust? On the one hand, perhaps Bishops' and KJV wished to make clear that the verses referred to all Christians, not just to Catholics who venerated relics. On the other, Geneva provides one of its notorious 'bitter notis' to observe that '(some read)' that the filthy cloth was a menstrual rag, a parenthetical aside that Protestant divines transform into a figure to express disgust at Catholic robes and idolatry. ${ }^{25}$ Astutely, Read notes the transformation of 'menstruous' to 'monstrous' in these texts, and connects it to the putting off of showy, contaminating Catholic idolatry but, surprisingly, she does not link this habit in the Protestant texts to the debates surrounding representation, decoration, or even to the emerging split between public and private that she otherwise identifies as characteristic of menstruation (a private process that threatens to make female fertility public).

22 The Holy Bible... in the earliest English versions made from the Latin Vulgate by John Wycliffe and his Followers [Wycliff, Early], ed. the Rev. Josiah Forshall (Oxford, I850); The Holy Bible ... in the earliest English versions made from the Latin Vulgate by John Wycliffe and his Followers [Wycliffe, Late], ed. the Rev. Josiah Forshall (Oxford, I850); Myles Coverdale, Biblia ([n.p.], I 535); The Byble in Englysh[Great Bible] (London, I540); The Bible [Thomas Matthew Bible] (London, I549); The Holie Bible [Bishops' Bible] (London, I 568), all reprinted in Chadwyck-Healey, The Bible in English (Cambridge, I996), last accessed through GALILEO, University of Georgia, I December 2012.

23 Miles Coverdale, Biblia ([n.p.], I 535), Chapter XXX, Fo. xi, Bbbsr, col. 2.

24 The Holie Bible ([n.p.], I610), Ooo2v, Vuu3v.

25 Records of the English Bible, ed. Alfred W. Pollard (London and New York, I9I I), pp. 297-8. 


\section{PASSION PLAYS IN SHAKESPEARE}

In the pens of Protestant commentators, however, these Biblical verses about idol-worship and righteousness become evidence of God's disgust towards: the trappings of the Catholic mass; the sacralization of relics; and the performance of good works. In opposition, Protestants offer humble, even abased, prayer; the importance of words rather than things; and the experience of personal faith. Most of the Protestant examples I have found (from slightly earlier than Read's) connect the verses from Isaiah to clothing, display, and performance (the performance of good works, and the performance of, as we shall see, stage-plays). Anthony Gilby, urging his fellow-Protestants to put away priestly apparel along with 'images' and 'ornaments,' cites Isaiah 30:22 in his justification:

You shall, sayth he, put out the couerynge of the Imagis of syluer, \& the precious vestyme[n]ts of the golde[n] Imagis, and thou shalt caste them awaye lyke a menstrous clowte, and saye vnto yt: Auawnte, or get the hence. Fynallye when all godly men abhorre the monstrous ap | parell of Fryers, Monkes, Chanons, I can not se, by what order they shulde exteme the ornaments of Popishe Preastes, whose order is as wyckyd as Freyers, Monkes, or any other. ${ }^{26}$

Richard Cavendish cites Isaiah to argue, once more, against works or doings, which are 'as menstruous clothes'. ${ }^{27}$ Laurence Tomson exhorts, 'what is he vpon the earth, that doth employ these wholy, [tha]t hath not alwayes [th]e flesh pricking against the spirit? then the work [tha]t is done of such, is it not as a menstruous cloth?'. ${ }^{28}$ And 'Our workes are al as the cloth [tha]t is defiled with menstruous bloud', writes the anonymous I.B. (possibly John Bale or John Bradford) in I 547. ${ }^{29}$ John Foxe's Acts and Monuments quotes Sir John Borthwick's arguments in the second article of his charges, against indulgences, as the latter attributes to the devil any good works done by saints:

I pray you, who taught those saints to worke or deserue for other, but only Sathan, who would vtterly haue [th]e merits of Christ extinguished and blotted out, which he knoweth to be the onely remedy of saluation? For if the Scripture do teache vs that no man of himselfe can deserue or worke their saluation, how did the saints then worke or merit for others... Besides this, all that which may be deserued or merited in the righteousnes of man, in the 64. chapter of Esay, they are compared vnto the garment menstruous \& defiled, to be cast out..$^{30}$

There are many more examples - such as those in the I 574 English translation of Niels Hemmingsen's The Preacher; the I58 I edition of John Foxe's response to the Portuguese bishop Joseph Osorio (translated into English by James Bell and compiled by Walter Haddon), which refers to menstruous cloths in the context of humble Protestant piety and histrionic Catholic pomp no fewer than seven times; Michael Drayton's i6 I o Heavenly Harmony; or Bartimaeus Andrewes' commentary on the Song of Songs. The Protestant church, writes Andrewes, is black with afflictions and neglect, but luckily the 'painted harlottes' of Catholicism toil in vain: Jesus, the divine Bridegroom, 'wil not be taken in their beauty for it is but a menstruous cloth unto him'. ${ }^{3 \text { I }}$ Some writers develop the figure further by contrasting rags stained with menstrual blood to pieces of whole-cloth dipped into and dyed in the blood of Christ. If the performance of works comprises stinking clouts sodden with menstrual flux, then faith, in the words of John Prime, is the fragrant 'peece of purple died in the bloud of Christ' and, according to the sermons of Nicholas Byfield, 'our practise should be died in the blood of Christ, and [s] auour of the vertue

26 Anthony Gilby, To my louynge brethren that is troublyd abowt the popishe aparrell (Emden, I 566), B Ir-v.

27 Richard Cavendish, The image of nature and grace (London, I 57I), P2v.

28 Laurence Tomson, An ansvvere to certein assertions (London, I 570$), \mathrm{JIV}$

29 I.B., A bryefe and plaine declaracion (London, I 547), A3v.

30 John Foxe, Actes and monuments (London, I 583 ), KKK $4 \mathrm{~V}$, p. I26I.

3I Niels Hemmingsen, The preacher, or Methode of preachinge (London, I574), Hir; Michael Drayton, A Heauenly Harmonie (London, I6Io), Fiv; Walter Haddon, John Foxe and James Bell, Against Ierome Osorius Byshopp of Siluane in Portingall (London, I58I), passim; Bartimaeus Andrewes, Certaine very vvorthy, Godly and profitable sermons vpon the fifth chapter of the Songs of Solomon (London, I 595), H2v. 


\section{SUJATA IYENGAR}

of his death'. ${ }^{32}$ (And if the new sandalwood dyes were used to colour the wool 'brick red', the vat might indeed 'sauour' or be perfumed with faith. ${ }^{33}$ )

The most interesting translation of this figure for Shakespearians appears in the antitheatrical literature, as low-church ministers transformed the Protestant prohibition on images, relics and Catholic vestments used in worship into a Puritan ban on representation, props and costumes used in stage-plays (compare the attacks and defences surrounding ornament in poetry that are also current at this time).${ }^{34}$ Philip Stubbes compares the sin of pride to menstrual rags, not directly in his diatribe against 'filthie plays and enterluds' but in his sections on pride of heart and pride of apparel. ${ }^{35}$ Philoponus defines 'pride of the heart' as the state of mind

whe[n] as a man lifting him selfe on highe, thinketh of himself, aboue that which he is of himselfe: dreamyng a perfection of himselfe, when he is nothyng lesse: And in respect of himselfe, contempneth, vilefieth and reproacheth all men, thinking none comparable to him selfe, whose righteousnes, notwithstanding, is lyke to the polluted cloth of a menstruous woman. ${ }^{36}$

Later, when his interlocutor Spudeus asks about whether people in other times cared so much for fashion as do, Spudeus claims, sixteenth-century townsfolk, without respect to age, sex, or calling, Philoponus responds pithily, 'King Pirrus sente riche attyre to the Matrones of Rome, who abhorred them, as menstruous clowtes.' ${ }^{37}$

The anonymous 'I.H.' in I6 I 5 deploys the comparison as part of a conceit that compares the city of London to a woman and its theatres to her sexual organs, both breasts and genitals. The World's Folly complains that London is full of the seven deadly sins, especially swearing, as citizens emulate the 'obscaene and light ligges, stuft with loathsome and vnheard-of Ribauldry, suckt from the poysonous dugs of Sinne-sweld Theaters'. ${ }^{38}$ In a section that specifically discusses play-houses, the author complains that more persons attend 'playing houses, than praying houses', where they hear 'Roaring
Meg (not Mol)', Scythian barbarisms, and oaths on stage. ${ }^{39} \mathrm{He}$ singles out the Curtain theatre in a pun that characterizes audience-members as sexually voracious clients and popular playwrights as their paramours, eager to satisfy them, and concludes with an admonition to the city authorities:

Those also stand within the stroke of my penne, who were wont to Curtaine ouer their defects with knauish conueyances, and scum off the froth of all wanton vanity, to qualifie the eager appetite of their slapping Fauorites. Then surely neither can Gods wrath be qualified, nor his pestilential arrows, which fly amongst vs by day, \& lethally wound vs by night, be quiuer'd vp, till these Menstruous Ragges be torne off (by the hand of Authority) from the Cities skirts, which so besoyle and coinquinate her whole vesture..$^{\circ}$

In case we fail to understand the analogy, he glosses 'menstruous ragges' with a marginal note: 'Bawdy players'. So London is what we might call (with acknowledgement to Patricia Parker) a 'Literary Fat Lady': ${ }^{\text {I }}$ the suburbs are her outskirts or outer garments; the theatres are her breasts engorged not with sustaining maternal milk but with 'loathsome ... poyson'; the stage or playing space is her pudendum; the plays they perform are a sexualized or obscene discharge such as menstrual blood or (in the description of the Curtain) 'froth' or semen provoked from male observers by her actions, or from her own body as she pleasures herself; and the actors upon that stage are the rags sewn to the skirt

32 John Prime, A Fruitefull and briefe discourse in two bookes (London, I583), G3r; Nicholas Byfield, Sermons vpon the first chapter of the first epistle generall of Peter (London, I6I7).

33 Eric Kerridge, Textile Manufactures in Early Modern England (Manchester, 1985), p. I67.

34 Barbara Lewalski's Protestant Poetics and the SeventeenthCentury Religious Lyric (Princeton, 1984) provides the definitive overview of this debate.

35 Philip Stubbes, Anatomie of Abuses (London, I 583 ), L $5 \mathrm{v}$.

${ }^{36}$ Anatomie of Abuses, B6r-v.

37 Anatomie of Abuses, D3v.

${ }^{38}$ I.H., The World's Folly (London, I6I 5), Biv-B2r.

39 The World's Folly, B2r.

40 The World's Folly, B3r.

${ }^{41}$ Patricia Parker, Literary Fat Ladies: Rhetoric, Gender, Property (London, 1987). 


\section{PASSION PLAYS IN SHAKESPEARE}

or to the shift to absorb the contaminating fluid (the rare and obsolete word 'coinquinate', meaning to defile or pollute, nicely evokes 'iniquity' although the latter is not part of its etymology). The account has a certain interest for social historians, too, since it suggests that, despite the debate surrounding whether or not women wore underwear on their lower bodies in this era, they did not (as a few twentieth-century popular accounts have it) leave an uninhibited trail of blood wherever they went, or bleed into their outer clothing. ${ }^{42}$ Read (who does not discuss this example) remains carefully neutral on this topic, suggesting that menstrual protection might vary from one woman to another depending on class, health, profession, and so on, so that prostitutes might insert sponges as absorbent pessaries while they menstruated so that they could continue serving clients; nobly-born women might use folded linen clouts or rags that were attached to a girdle; poorer women with no linen to spare might bleed into their shifts, which might or might not be knotted between the legs. She writes that there is no evidence that women sewed cloths for menstrual protection. But this antitheatrical tract, and Rainolds', below, clearly imagine the rag as something separate from the skirt, that can be removed from it - perhaps a bit like a bum-roll (a cushion tied around the hips to pad them, in lieu of a farthingale). ${ }^{43}$

Finally, the well-known antitheatrical tract, The Overthrow of Stage Plays (I599) by John Rainolds, President of Corpus Christi, Oxford, combines three concerns of early modern life anti-theatricalism, sexual dimorphism, and the rag-paper cycle - when he compares putting actors on stage to perform plays to giving Phaedra a 'menstruous cloth' to hold during her 'amorous speech' in Seneca. ${ }^{44}$ The analogy appears within a passage that contrasts Quintilian's restricted curriculum for students with the licentious programme of present-day teachers and scholars. On the one hand, argues Rainolds, Quintilian prohibits both literature, such as 'amatorie poemes', and certain methods of delivery, such as 'imitat[ing] the voices of Women, or old men' because 'such as those are whom we imitate much, such our selves become'. ${ }^{45}$ On the other, continues Rainolds,

you, as if Phaedras amorous speech expressed by Seneca were nothing without a peece of menstruous cloth sowed to it, doe occasion yours to make them selves familiar and well acquainted with Plautus, one farre beneath the best. He would haue his youth to practise their style in good things, as in weapons, which they may vse when neede shall be: you practise yours in speeches entising men to Uenerie, to ribauderie, to scurrilitie, to hoordom, to incest, to other abominations. He would haue his youth to commit most excellent thinges and wordes to memorie; you pester yours with filth, such filth in Rivales (I am ashamed to reherse it) as can not be matched, I thinke, sure very hardly, throughout all Plautus. Hee would not haue his youth to counterfeit a womans voice: you procure Minerva, Penelope, Euryclea, Antonoë, Eurynome, Hippodamia, Melantho, Phaedra, the Nurse, the Nymph, besides I know not whom in the vnprinted Comedie, to bee played by yours. ${ }^{46}$

Rainolds' 'menstruous cloth' evokes disgust and contamination, the viscerally physical, through the incongruity of high classical culture and low material object, manly verbal swordplay and feminine logorrhoea, tragic, extraordinary love and banal, monthly bleeding. Rainolds chooses this image because what menstruous rags and stage-plays share is their ability to foreground - obscenely - gender and binary sexual difference in the observer's mind.

The analogy breaks down somewhat when we take it apart. For one thing, the passage begins by comparing both stage-acting and the works of Plautus to menstrual rags, but then attempts to recuperate Plautus somewhat by implying that where written (printed?) tragedy and the works

\footnotetext{
42 See, for example, Harry Finlay's online MUM: Museum of Menstruation, which misrepresents or misunderstands Read's argument to suggest that 'When [women] menstruated, they left a trail of blood behind them', www.mum.org/pastgerm. htm. Date of last access: 22 November 2013

43 OED, bum, sb. I, C2.

44 John Rainolds, The Overthrow of Stage-Plays (London, I 599), Q3v.

45 The Overthrow of Stage-Plays, Q3r.

${ }^{6}$ The Overthrow of Stage-Plays, Q3v.
} 


\section{SUJATA IYENGAR}

of Seneca might immortalize 'the best', or 'good things', or even 'excellent thinges and wordes', in contrast, 'unprinted Comedie[s]' or extempore performance that includes female impersonation is even worse than Plautus's comedies. The common stage-property of the bloody handkerchief becomes a functional and overwhelmingly female object, the product of material processes rather than the work of imagination.

Rainolds' metaphor additionally suggests that the acting of 'unprinted comedies' threatens to turn printed paper - Seneca's tragedies - back into the rags from which paper was made. The obscene parody extends to bibliography: bookbinders folded and sewed printed sheets into books just as women folded and sewed 'menstruous cloth[s]' into absorbent pads. These rags' limited ability to absorb blood flow leads to our only direct Shakespearian reference to menstruation, the 'good old Lord' Gonzago's description of a sinking ship as 'leaky as an unstanched wench' (The Tempest I.I.45-6). Rainolds seems to say by his analogy that stage-plays make visible something that should be excluded or hidden, that is, they evoke sex in both its (modern) senses, erotic contact and sexual difference.

The menstrual stain in anti-theatrical literature corresponds to what Jonas Barish calls the 'fearful aversion to anything . . . that might suggest active or interested sexuality, this being equated with femininity, with weakness, with the yielding to feeling, and consequently with the destruction of all assured props and boundaries' that he finds in the work of William Prynne and other anti-theatrical writers. ${ }^{47}$ Stage-plays can't represent women's bodies but they make viewers think about them all the more, all the same, as Stephen Orgel has argued. ${ }^{48}$ One could respond that women's bodies are more vividly objectified and estranged through their representation, as does Dympna Callaghan in Shakespeare Without Women. ${ }^{49}$ But these gendered bodies on stage are also estranged from supposedly inherent or corporeal moral, social, intellectual qualities. Shakespeare's bloody rags foreground the art and act of representation in order to critique gender that is socially enforced.

\section{'BLOODY PASSION'}

We know that cross-dressed boys who played women's parts stimulated a high level of cultural anxiety around questions of gender, sexuality and representation in early modern England; Shakespeare's plays artificially sustain and develop this anxiety as they combine references to crossdressing with the stage-property of the bloody or stained rag and the experience of what is (with one exception, with which I'll conclude) called 'passion'. Let's take Shakespeare's stained and spotted napkins in order once more. In 3 Henry VI, I.4, Queen Margaret taunts the imprisoned Duke of York by mocking him on a mole-hill, crowning him with paper, and - cruellest of all - bidding him weep, and wipe his tears with a handkercher steeped in the blood of his murdered child the young Duke of Rutland. Many have noted the evident parallels with Christ's Passion and Crucifixion - the crown of thorns becomes a crown of paper, the mole-hill stands for Calvary, and the bloody rag parodies St Veronica's vernicle or handerchief mystically imprinted with the image of Christ's face after she mops his brow. Northumberland responds to York's tears as to a Passion Play: 'Beshrew me, but his passion moves me so / That hardly can I cheque my eyes from tears' (3 Henry VI, I.4.I5I). ${ }^{50}$ York's response to Margaret, however, focuses upon her sex and gender, upon her unnatural relationship to blood and to the bloody rag she waves in his face, in particular. Margaret is a 'she-wolf of France', 'ill-beseeming . . . in [her] sex', an 'Amazonian trull', and thus, in the

\footnotetext{
47 Jonas Barish, The Anti-Theatrical Prejudice (Berkeley, I98I), p. 85 .

48 Stephen Orgel, Impersonations (Cambridge, I996).

49 Dympna Callaghan, Shakespeare Without Women (London and New York, 2000).

so Northumberland's phrase presents a crux: the octavo The True Tragedie of Richard Duke of York (London, I595) gives 'passions moue' (B2v), but F gives 'passions moues' (TLN 552). I follow the New Cambridge emendation 'passion moves' here because the scene so clearly establishes York as a Christ-figure and his suffering as a passion. See The Third Part of King Henry VI, ed. Michael Hattaway (Cambridge, I993).
} 


\section{PASSION PLAYS IN SHAKESPEARE}

false and common early modern etymology for Amazon, lacking a breast, the source of that most benign of early modern female fluids, mother's milk (I.4.II2-I5). Where true women are 'soft, mild, pitiful and flexible', Margaret is 'stern, obdurate, flinty, rough, remorseless' (I.4.I42-3).

In the comic register, the parodic play of Pyramus and Thisbe in A Midsummer Night's Dream 5.I prominently features Thisbe's bloodstained mantle, as the Prologue informs us:

as she fled, her mantle she did fall,

Which Lion vile with bloody mouth did stain.

Anon comes Pyramus, sweet youth and tall,

And finds his trusty Thisbe's mantle slain;

Whereat, with blade - with bloody blameful blade -

He bravely broached his boiling bloody breast.

$(5 . I .14 \mathrm{I}-6)$

The alliterative repetition of 'bloody' with 'bravely', 'blameful' and 'boiling' comically emphasizes the stage-property, as does Pyramus/ Bottom's rant when he discovers it in clumsy dimeter: 'Thy mantle good /What, stain'd with blood', an ejaculation that almost immediately prompts Theseus's mock-sympathetic riposte, 'This passion - and the death of a dear friend would go near to make a man look sad' (5.I.277-8, 283-4). More mysterious is Demetrius's comment, 'A mote will turn the balance which Pyramus, which Thisbe, is the better - he for a man, God warrant us; she for a woman, God bless us' (5.I.3 I $3-5$ ). The Folio stops at 'better', omitting both the profanity (the name of God) and the obscure reference to sexual difference. Ronda Arab suggests that Demetrius accuses the asinine Bottom/Pyramus of being only as close to a man (that is, a human being) as Flute/Thisbe is to being a woman (that is, a female)..$^{51}$ Certainly the play has made much of the technologies of female impersonation that the mechanicals use, and to the secondary sexual characteristics that, Flute claims, will impede his performance: 'let me not play a woman. I have a beard coming' and Thisbe's lament, which Theseus characterizes as 'her passion [which] ends the play' describes Pyramus in terms more traditionally associated with the female mistress of Petrarchan poetry, as Harold Brooks notes in his Arden 2 edition (I.2.43-4, 5.I.3 Io). ${ }^{52}$ There may also be (as in As You Like It and in Sonnet 20) a pun on 'for a man' and 'for a woman': both Pyramus and Thisbe are equally unappealing sexually, to men and to women. ${ }^{53}$ The mantle works to gender neither Flute as fainting female nor Pyramus as valiant swain, managing to evoke a monstrous parody of the Passion and an impersonation of sexual difference played 'most obscenely and courageously' (I.2.IOO-I). ${ }^{54}$

As You Like It calls attention to Rosalind/ Ganymede's swoon at the sight of the 'napkin' stained with Orlando's blood as a mark of her femininity and of her heteroerotic love for Orlando (4.3.94). Both Oliver and Celia draw attention to the relationship between blood, gender, and passion (I quote at length and intersperse commentary because the play, and Rosalind, just won't let it go):

Oliver. He sent me hither, stranger as I am, ... to give this napkin, Dyed in his blood, unto the shepherd youth That he in sport doth call his Rosalind.

$(4 \cdot 3 \cdot 153-7)$

Note that Oliver couples the name of Rosalind with blood both times he utters it, first as he seeks out Ganymede and introduces himself, "to that youth he calls his Rosalind / He sends this bloody napkin', and second as he intensifies the echoes of the sacrificial Biblical passion through the phrase 'dyed in his blood' and the evocation of the 'shepherd' and the 'rose' in Rosalind (4.3.93-4).

CELia. Why, how now, Ganymede, sweet Ganymede! OLIVER. Many will swoon when they do look on blood.

${ }^{1}$ Ronda Arab, Manly Mechanicals on the Early Modern English Stage (Cranbury, NJ, 20I I), p. I Iо.

52 A Midsummer Night's Dream, ed. Harold Brooks, Arden Shakespeare, Second Series (London, I979), pp. I2 I-2.

53 As You Like It, Epilogue; Sonnet 20, line 9.

54 Patricia Parker argues that the scene additionally parodies Christ as Divine Bridegroom: 'What's in a Name: and More', pp. IоI-49. 


\section{SUJATA IYENGAR}

CELIA. There is more in it. Cousin Ganymede! OLIVER. Look, he recovers.

$(4 \cdot 3 \cdot 158-6 \mathrm{I})$

Celia instinctively rallies Rosalind with her boyname, Ganymede, although she cannot resist correcting Oliver's misapprehension when he assumes that Ganymede swoons from cowardice (which makes his heart quail or shrink, preventing it from producing enough vital spirit for its own sustenance) when faced with the sight of blood. Instead, she implies (and the audience knows), 'the more in it' is female perturbation, fear, and sorrow, and the inability of Rosalind to voice her grief to vent the excess blood that has rushed to sustain her fainting heart, that makes Ganymede swoon. Oliver offers a diagnosis that is more apt than he realizes: 'Be of good cheer, youth. You a man? You lack a man's heart' (4.3.165-6). She does indeed 'lack a man's heart', and Rosalind's smaller heart is overwhelmed or o'ercharged by emotion. Rosalind responds, 'I do so, I confess it. Ah, sirrah, a body would think this was well counterfeited. I pray you, tell your brother how well I counterfeited. Heigh-ho!'(4.3.I67-9). Ganymede overcompensates for the pair of feminine signifiers: a bloody rag and, as Oliver goes on to say, 'passion of earnest' (4.3.I7I-2). Even as Ganymede insists he was 'counterfeiting,' Rosalind responds to Oliver's injunction, 'Well then, take a good heart, and counterfeit to be a man', with the joke, 'So I do; but, i'faith, I should have been a woman by right' (4-3.174-7). Perhaps Celia's observation, 'you look paler and paler' is both medically accurate (as the blood retreats to Rosalind's heart during her passion) and tactful (4.3.I78). Oliver's exit lines hail Ganymede straightforwardly as Rosalind, as if the masquerade is over definitively in his mind: 'I must bear answer back / How you excuse my brother, Rosalind' (4.3.I80-I). Ganymede still claims to be 'counterfeit[ing]', but Oliver probably realizes that the former's faint was more than a feint.

Although Desdemona's handkerchief is strawberry-spotted, rather than explicitly bloodstained, the play uses it to associate women and blood with performance. This handkerchief's blood-stains are figurative, not literal, because its characters remain trapped within a web of representation. ${ }^{55}$ If the play seems less overtly concerned with gender exchange than As You Like It or 3 Henry VI, then both the images of Desdemona's body 'tasted' by the whole camp and Othello himself 'eaten ... with passion,' and the famous textual crux, 'Her (My) name, that was as fresh / As Dian's visage, is now begrimed and black / As mine own face' mix up the lovers' identities in the 'chaos' that Othello himself dreads $(3 \cdot 3 \cdot 390-3)$. Throughout the play Othello's excessive jealousy, his public and private anger, and (by Iago) his 'grief' are called 'passions'. The development, or rather, the degradation of these 'passions' tracks Iago's theatrical plot, as does the figurative staining or contamination of the handkerchief, from a token of love to a token of jealous and bloody murder. '[P]assion... Essays to lead the way' as Othello, angered, strives to discover 'How this foul rout [Cassio's drunken aggression, instigated by Iago] began' (2.3.I99-200, 203). In the so-called temptation scene, $3 \cdot 3$, Othello praises Iago as one whose 'heart / ...passion cannot rule' (I28-9); Iago's insinuations trigger the headache that Desdemona tries vainly to heal by binding her husband's brows with her 'too little' napkin (29I). (If Othello suffers from epilepsy, the strawberry-spotted handkerchief resembles to some degree the blood-soaked linen plasters bandaged around the temples of epilepsy sufferers in the new Paracelsian therapies, or recalls the menstrual blood to be drunk, warm, by epileptics in the new pharmacopoeia. ${ }^{56}$ ) After we learn that Iago has long planned to steal the handkerchief, and watched Emilia take it up, Othello returns to the stage, where, Iago observes, he is 'eaten up with passion' $(3 \cdot 3 \cdot 396)$. Othello's 'trance' in 4.I. follows a well-known speech that

\footnotetext{
55 On representation, rhetoric, and identity in Othello, see Joel Altman's magisterial The Improbability of Othello: Rhetorical Anthropology and Shakespearean Selfhood (Chicago and London, 2010).

56 Louise Noble, 'The Fille Vièrge as Pharmakon: The Therapeutic Value of Desdemona's Corpse', in Disease, Diagnosis, and Cure on the Early Modern Stage, ed. Stephanie Moss and Kaara L. Peterson (Aldershot, 2004), p. I49 n.43.
} 


\section{PASSION PLAYS IN SHAKESPEARE}

associates the handkerchief with Passion (with 'God's wounds', abbreviated into the common profanity) and passion:

Lie with her? Lie on her? We say 'lie on her' when they belie her. Lie with her? 'Swounds, that's fulsome! Handkerchief - confessions - handkerchief. To confess and be hanged for his labour. First to be hanged and then to confess! I tremble at it. Nature would not invest herself in such shadowing passion without some instruction. It is not words that shakes me thus.

(4.I.34-40)

The 'shadowing passion' is both the looseness of Cassio, in his alleged erotic dream, where night shadows or reflects the events and thoughts of the day, and the convulsive 'grief' ('A passion most unsuiting such a man', reproves Iago) that cripples Othello himself, where Iago's words cloud Othello's reason (put him in shadow) and call up, as instructions to an actor, the emotions demanded by the script (4.I.76). To Othello, Desdemona now merely shadows or plays 'well-painted passion', like an actor, when she weeps (4.I.258), and to Lodovico, Othello's fall from 'the nature / Whom passion could not shake' denotes that he must have lost his 'wits' (4.I.267-8, 27I). Lodovico almost suspects a script - that 'letters [did] work upon his blood / And new-create his fault' - but cannot conceive of the true author (277-8). Finally, Desdemona calls Othello's jealous rage in 5.2 his 'bloody passion', and Othello just a few lines later returns to harping on 'That handkerchief' $(5.2 .47,50)$, whose 'work' could not be 'ta'en out' $(3 \cdot 3 \cdot 300)$ as easily as Emilia had imagined.

When we move to Cymbeline, Shakespeare includes the characteristic pattern of gender reversal, metatheatrical reference, and spotted rags that I have described in 3 Henry VI and As You Like It, but crucially omits a term that hitherto has accompanied it. I end this survey of bloody Shakespearian passions with a development or maturity in Shakespeare's career, or at least an imaginative response to the exigencies of the emerging genre of tragicomedy. The bloodstained napkin in Cymbeline provides the (faked) evidence of Innogen's death that Pisanio somehow gets to Posthumus in the Roman camp. Posthumus finds the supposed 'testimonies [of Innogen's infidelity] lie bleeding in [him]' (3.4.22-3); Innogen 'forget[s] to be a woman' (3.4.155) and dresses as the youth Fidele, and Posthumus (at least according to the stagetradition discussed by Valerie Wayne) wears on his body Innogen's bloody rag. But this play lacks passion, despite its 'bloody cloth' (5.I.I). I mean that literally: the word 'passion' does not appear in this play. Innogen is chaste to a fault, some argue, denying her husband even the 'lawful pleasure' of marital intercourse, even as she displays (in a phrase that is at best salacious and at worst pornographic) 'a pudency so rosy the sweet view on't' would have charmed Saturn himself (Cymbeline 2.5.9, I I). Innogen perhaps remains amenorrhoeic, free from the 'passion menstruall' as from the passion sexual.

More appealing, however, is the surmise that this play lacks not mutual erotic passion but suffering passion (from the Latin patior, passus sum, I suffer, I suffered, but also I allowed, and I am patient). Faced with Pisanio's evidence, Posthumus (to our surprise and relief, if we are familiar with the plot of the slandered lady from $A d o$ and Othello) repents his jealousy almost instantly, even if he imagines his wife to have been possibly 'wrying but a little' (5.I.5): he experiences no 'bloody passion' such as tortures Othello. Similarly, Innogen suffers patiently rather than passionately: unlike Desdemona, she does not cry 'Am I that name?' but resists her misogynistic hailing by performing a different sex (Othello, 4.2.I2I); unlike Juliet (Thisbe's tragic counterpart), neither when she finds herself accused of adultery nor a seeming widow does she think to kill herself. Perhaps the play lacks Passion, too - Innogen does not need to become a redemptive sacrifice as does Desdemona, and nor does Posthumus need to kill himself as does Othello. The play also lacks the imagery of eating and consumption that, as Stephanie Moss and others have noted, characterizes Othello, and Desdemona's sacrificed or mummified corpse in particular. ${ }^{57}$ Instead, perhaps Cymbeline's hero is

57 Stephanie Moss, 'Transformation and Degeneration: The Paracelsian/Galenic Body in Othello', in Disease, Diagnosis and Cure on the Early Modern Stage, pp. I 5 I-I 70. 


\section{SUJATA IYENGAR}

'Posthumus' in its adjectival sense, in the sense that he, like Innogen, is reborn from the dead (since Innogen believes he is dead, having mistaken Cloten's headless corpse for Posthumus's body earlier in the play). This is Redemption without Passion but with and through the Play - Passionately Secular, Passionately Theatrical, and Passionately Pagan, Shakespeare.

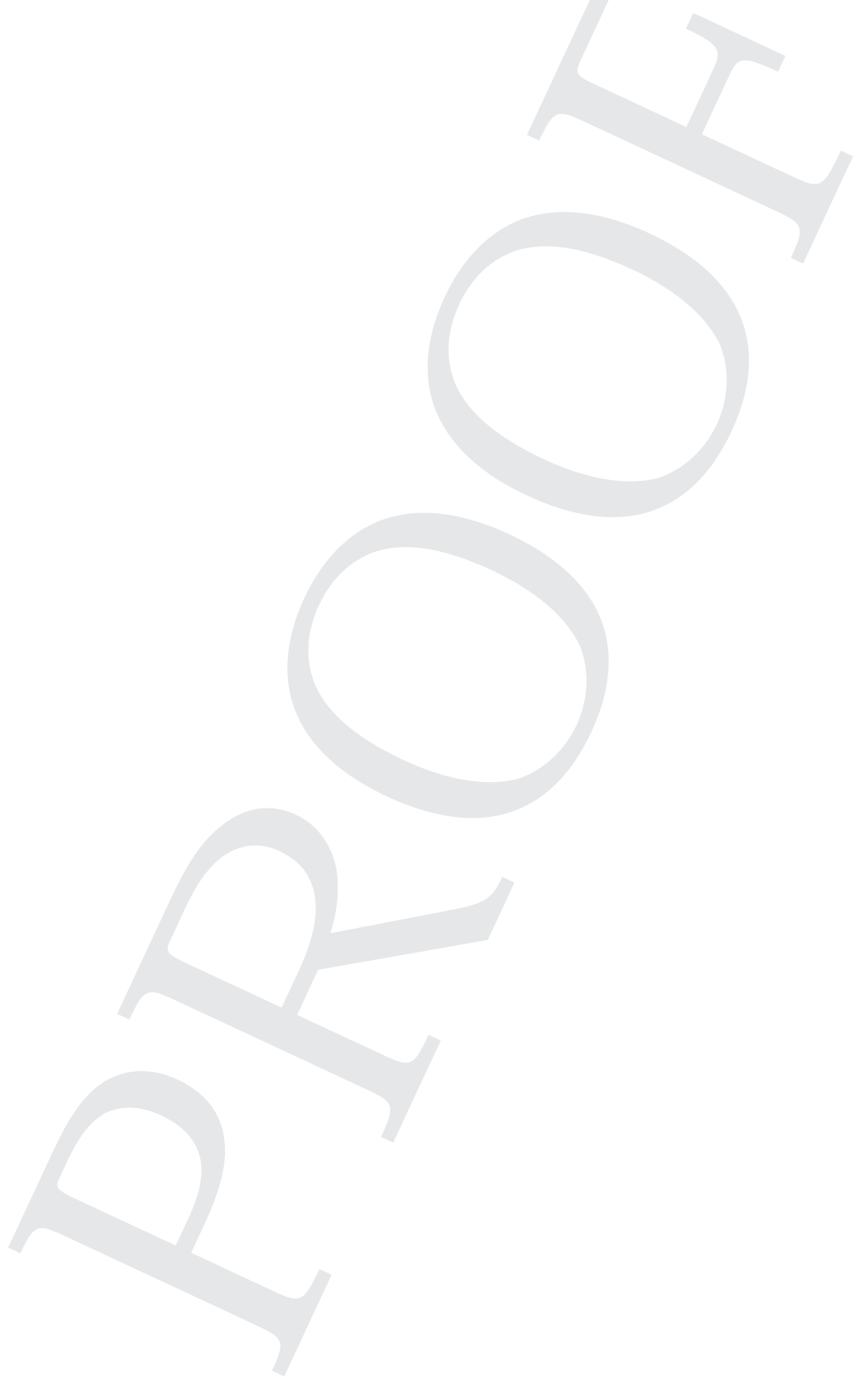

